Tehran in November 1979 on a private mission to try to get the American diplomats released from their captivity. He also continued to consult with the State Department throughout the 1980s, when the Reagan Administration found itself entangled in a complicated web of foreign policy initiatives with Tehran and in Lebanon.

It is important to note that Dick did not believe that he had the answers to the problems that were troubling US-Iranian relations. But he did believe very passionately that the relationship needed to be re-examined in the clear light of day, and without ideological blinkers. It might be thought that he was an advocate of Iranian nationalism, but nothing could be further from the truth. It would be more accurate to say that he was convinced of the formative power of nationalist beliefs, and that any disregard of that power was bound to be counterproductive. For the rest, he had a healthy skepticism of any emotionally driven point of view. The academic and policy worlds have lost a major voice of reason and understanding. And for those of us who were fortunate enough to have known him, we have lost a mentor, colleague, and friend.

SHAHROUGH AKHAVI University of South Carolina

NOTES:

1. Mark J. Gasiorowski, "The Qarani Affair and Iranian Politics," International Journal of Middle East Studies, 25:4 (November 1993), p. 628, 641, fn. 12. Gasiorowski does not explicitly name the individual, but it may be presumed that it was Dick Cottam. The article appeared under the title, "Unrest is Viewed as Threat in Iran," on 2 January 1958, p. A5.

2. Gasiorowski, p. 638. Again, Cottam is not specifically identified by Gasiorowski, but it seems likely that he was involved. Gasiorowski makes the point that having the Embassy not inform the Shah of what Qaranah'i was up to was likely not the position of Allen Dulles or Richard Helms, then head of CIA's covert operations division, but rather the preference of a senior official in the Agency's Middle East section.

3. Pitt Magazine, March 1988, p. 32.

4. Foreign Policy, 34 (Spring 1979), pp. 3-14.

\title{
Richard Cottam: An Appreciation
}

Richard Cottam, a CIA agent in Iran in the early 1950s and one of the most eminent American Iran scholars, was also a patriot. In 1972 I was a Foreign Service Officer enroute to assignment in Embassy Tehran. Having no experience with the country, I asked the State Department desk officer to recommend background reading. "There are no books on modern Iran," he replied. Cottam's Nationalism in Iran had been out eight years, I learned later. Dick wasn't read, but he also wasn't seen at the State Department. In those days there was no contact with the Shah's opposition. Dick befriended those people. Thus, there was no contact with him. 
Dick pushed against that barrier in the early fall of 1978 when the Shah's opponents were gathering massive strength. He asked to bring Ibrahim Yazdi, an aide to Khomeini, to see Gary Sick in the White House. Too high up, someone decided; better that he talk to me, newly become the desk officer for Iran. I agreed and set an appointment. Undersecretary Christopher got wind of it and directed that I cancel. In doing so, I established contact with Cottam and later, through him, with Yazdi.

During the Christmas holidays that December Cottam went to Tehran and, at our request, visited the Embassy, putting the staff in touch with key members of Khomeini's circle, among them Ayatollah Mohamed Beheshti. When the Embassy was seized by an armed group on Valentine's Day after the fall of the Shah, Beheshti and Yazdi came to the compound to free Ambassador Sullivan and his staff. We had Cottam's introductions to thank for that rescue.

He continued to advise us during the confused, sensitive period of the Bazargan provisional government in 1979. In September Foreign Minister Yazdi told me they hoped Cottam would be named US Ambassador. The trust and respect revolutionary Iranians felt for him might have made a difference in our dealings with Tehran. It might have made a difference if he, rather than Ramsay Clark, had been picked as Presidential envoy to Khomeini when the hostages were taken.

During the Hostage Crisis our biggest problem was to find someone to talk to in Tehran. After a bit, Cottam reached another old contact, then Foreign Minister Sadeqh Ghotbzadeh. Through their almost daily telephone calls we could at least communicate indirectly. But power was by then fast slipping away from Cottam's circle of oppositionists.

The relationship between the State Department and Cottam was a strange one, moving over the years from early consultation to hostility to near dependency. Always a very hard country to understand, Iran's high garden walls which sheltered kin and friends and excluded strangers represented a political reality. If we had listened to Cottam, those walls might not have seemed quite so high.

HENRY PRECHT

Bethesda, Maryland

James Douglas Pearson (1911-1997) died on 1 August 1997 having suffered a stroke a week previously. Professor Pearson was one of the most eminent and pioneering librarians and bibliographers in the field of Middle Eastern and Islamic studies, and beyond that in Oriental studies generally. Born in December 1911, he grew up and was educated in humble circumstances in Cambridge. First employed in Cambridge University Library at the age of 16 as a book-fetcher, he developed a taste for, and skill in, "exotic" languages and was awarded a scholarship at St. John's College, graduating in Hebrew in 1936. He was then employed in the Oriental Section of the Library until 1941, when he was enlisted for war service until 1945. He worked again in Cambridge University Library as an Assistant Under-Librarian from 1945 until 1950.

In 1950 he was appointed Librarian of the School of Oriental and African Studies (SOAS) in London and until 1972 oversaw the drastic expansion and 